\title{
CRIME OU DESCONFIANÇA: COMO CAEM OS GOVERNOS NO PRESIDENCIALISMO BRASILEIRO E NO PARLAMENTARISMO
}

\author{
Luis Lima Verde Sobrinho ${ }^{1}$ \\ Filomeno Moraes ${ }^{2}$
}

\begin{abstract}
RESUMO
Este artigo desenvolve estudo sobre quedas de governo forçadas pelas ferramentas democráticas no Estado de Direito, a partir de comparativo entre o impeachment no presidencialismo brasileiro e o voto de desconfiança nos sistemas parlamentaristas, objetivando traçar os fundamentos de legitimidade e os limites de atuação, políticos e jurídicos, dos poderes sancionadores. Examina-se a responsabilidade política no presidencialismo brasileiro e a teoria dos crimes de responsabilidade imputáveis ao Presidente da República. Após, adentra-se o tema da responsabilidade política parlamentarista, dando-se ênfase ao estudo do voto de desconfiança. Conclusivamente, apresentam-se semelhanças e diferenças existentes entre os modelos de sanção política.
\end{abstract}

Palavras-chave: Impeachment. Parlamentarismo. Presidencialismo. Quedas de governo. Voto de desconfiança.

\section{CRIME OR MISTRUST: HOW GOVERNMENTS FALL IN THE BRAZILIAN PRESIDENTIALISM AND IN THE PARLIAMENTARISM}

\begin{abstract}
This article develops a study about government falls forced by the democratic tools in the rule of law, using a comparison between the impeachment in the Brazilian presidentialism and the vote of no-confidence of parliamentary systems, aiming at developing the basis of legitimacy and the action limits, political and legal, of the sanctioning powers. We examine the political accountability in the Brazilian presidentialism and the theory of liability offenses attributable to the President. Next, we enter the subject of the parliamentary political accountability, especially the study of the vote of no-confidence. In conclusion, we present similarities and differences between the models of political sanction.
\end{abstract}

Key-words: Impeachment. Parliamentarism. Presidentialism. Government falls. Vote of noconfidence.

\footnotetext{
${ }^{1}$ Mestre em Direito Constitucional pela Universidade de Fortaleza, Especialista em Direito Tributário pela Universidade Anhanguera-Uniderp e Graduado em Direito pela Universidade de Fortaleza. Membro do Grupo de Pesquisa Estado, Política e Constituição (CNPq/UNIFOR). Analista Judiciário e Assessor Jurídico da Presidência do Tribunal de Justiça do Estado do Ceará - TJCE.

${ }_{2}^{2}$ Doutor em Direito pela Universidade de São Paulo, Mestre em Ciência Política pelo Instituto Universitário de Pesquisas do Rio de Janeiro e Livre-Docente em Ciência Política pela Universidade Estadual do Ceará. Professor Titular do Programa de Pós-Graduação em Direito Constitucional/Mestrado e Doutorado da Universidade de Fortaleza. Líder do Grupo de Pesquisa "Estado, Política e Constituição" (CNPq/UNIFOR).
} 


\section{INTRODUÇÃO: A RESPONSABILIDADE POLÍTICA COMO FERRAMENTA DA DEMOCRACIA REPRESENTATIVA}

O princípio da responsabilidade política é o traço distintivo do Estado de Direito, e surge com a derrocada do absolutismo e a aparição das teorias modernas sobre separação de poderes e democracia, a partir do final do século XVII. Firmada a premissa de que a legitimidade e a autoridade política da soberania assentam-se na nação ou no povo, surgiu para os governantes o ônus de prestar contas aos governados (accountability), e é em torno desse dever que a teoria da responsabilidade política orbita.

A responsabilidade política pressupõe necessariamente o controle político dos atos dos órgãos constitucionalmente responsáveis pela gestão do Estado. Com efeito, "isso explicase porque o desígnio geral do Estado constitucional é que nenhum poder e nenhuma competência podem existir sem os correspondentes mecanismos de controlo e limitação" (LOMBA, 2008, p. 94-95). Nesse cenário, a construção das democracias constitucionais surgiu intimamente ligada aos conceitos de responsabilidade e representação políticas. A responsabilidade política está necessariamente vinculada ao sistema representativo. Quanto mais representativos, mais responsáveis são os titulares do poder político. O governo representativo é, pela sua própria natureza e definição, um governo condicionado por esse dever (LOMBA, 2008).

Feita a apresentação do tema a ser explorado, examinar-se-á a responsabilidade política no presidencialismo brasileiro e a teoria dos crimes de responsabilidade imputáveis ao Presidente da República, abordando-se, na sequência, os contornos do impeachment, enquanto processo e enquanto sanção. Passo seguinte, adentrar-se-á o tema da responsabilidade política no parlamentarismo, dando-se ênfase ao estudo do voto de desconfiança contra o governo. Ao final, será proposta a conclusão do artigo, na tentativa de responder à seguinte indagação: quais as semelhanças e diferenças existentes entre os dois modelos de sanção política?

Assim, o objetivo geral desta pesquisa é desenvolver estudo sobre quedas de governo forçadas pelas ferramentas democráticas no Estado de Direito. Os objetivos específicos são (i) estabelecer um comparativo entre o impeachment no presidencialismo brasileiro e o voto de desconfiança próprio dos sistemas parlamentaristas; e (ii) traçar os fundamentos de legitimidade e os limites de atuação, políticos e jurídicos, dos poderes sancionadores.

A pesquisa é do tipo bibliográfica, pois explica o problema a partir de referências teóricas; pura quanto ao resultado, porquanto tem por finalidade aumentar o conhecimento dos 
pesquisadores, sem implicar transformação da realidade; de natureza qualitativa, dado o caráter subjetivo do ensaio; explicativa no que atine aos fins, na medida em que identifica os fatores que determinam ou contribuem para a ocorrência de fenômenos; e dedutiva no que toca ao método utilizado, partindo de enunciados gerais para chegar a conclusões particulares.

\section{A RESPONSABILIDADE POLÍTICA NO PRESIDENCIALISMO BRASILEIRO}

A história do presidencialismo inicia-se com a Constituição norte-americana de 1787, que instituiu um regime baseado principal e quase unicamente na figura central do Presidente da República, acumulando as funções de Chefe de Estado e de Governo. Trata-se, portanto, de fórmula alternativa produzida por teoristas, reflexão doutrinária arquitetada pelos constituintes americanos daquele ano. Mais adiante, ver-se-á que, diferentemente do parlamentarismo, que decorre de um longo processo evolutivo, o presidencialismo, em boa medida, é produto da construção cerebrina dos Founding Fathers of the United States of America (BONAVIDES, 2015; HAMILTON, MADISON, JAY, 2003; KETCHAM, 2003; DAHL, 2003; HOFSTADTER, 1989).

No desenrolar histórico, entretanto, o presidencialismo apresentou mudanças. De início marcado por um processo político autoritário e centralizador em torno da figura presidencial, modernamente esse sistema conta com a ampliação dos poderes de controle parlamentar e judicial em relação ao Executivo, para garantia de maior estabilidade democrática (MORAES, 2013). Não obstante, o Presidente da República continua sendo Chefe de Estado, Chefe de Governo, Chefe Diplomático e Chefe das Forças Armadas (ROSSITER, 1940).

No Brasil não foi diferente: da proclamação da República presidencialista em 1889, passando pela promulgação da Constituição da República Federativa do Brasil (CRFB) de 1988, até chegar aos atuais dias de amadurecimento democrático, é perceptível a evolução do sistema de freios e contrapesos entre os três poderes e o crescimento da responsabilidade política do Presidente (MORAES, 2003) ${ }^{3}$. Nesse contexto, os elementos estudados pela teoria da responsabilidade política no presidencialismo brasileiro são os crimes de

3 Há quem veja no "presidencialismo de coalizão" brasileiro, pós-88, caraterísticas semiparlamentaristas. Entre outros, Figueiredo e Limongi (1999, p. 101) destacaram que "o sistema político brasileiro não opera de forma muito diferente dos regimes parlamentaristas", visto que os presidentes "formam governos" como o fazem os primeiros-ministros em sistemas multipartidários. 
responsabilidade, o impeachment enquanto processo parlamentar de apuração da responsabilidade presidencial e o impeachment enquanto sanção política de destituição do cargo em razão do cometimento de crime de responsabilidade. Frise-se que, aqui, por impeachment entende-se tanto o processo - art. 86 da Constituição, com a disciplina da Lei $n^{\circ} 1.079$, de 10 de abril de 1950 -, quanto a sanção aplicada ao final deste - art. 52, par. ún., da CRFB.

\subsection{Da natureza jurídica dos crimes de responsabilidade imputáveis ao Presidente da República}

A Constituição do Brasil prevê, em seus artigos 85 e 86, a possibilidade de responsabilização do Presidente da República, tanto por crimes comuns quanto por crimes de responsabilidade (aqui nos interessam os crimes de responsabilidade, porquanto os comuns constituem objeto de estudo da teoria da responsabilidade penal). O parágrafo único do art. 85 delega a uma lei especial a tarefa de disciplinar os crimes de responsabilidade e estabelecer as regras de processo e julgamento. A Lei $\mathrm{n}^{\mathrm{o}}$ 1.079/1950, recepcionada pela Constituição de 1988, é que define os crimes de responsabilidade e o rito do julgamento nas duas casas do Congresso Nacional. O art. 34 fixa a sanção aplicável a tais ilícitos: a destituição do cargo, também chamada de impeachment, vocábulo proveniente do constitucionalismo da Inglaterra. Além da destituição do cargo, prevista no art. 34 da Lei, a Constituição de 1988, no art. 52, parágrafo único, estabelece a concomitante inabilitação, por oito anos, para o exercício de função pública.

Nessa perspectiva, os crimes de responsabilidade, segundo o art. 85 da Constituição, são os atos que atentem contra a Constituição Federal e, especialmente, contra a existência da União, o livre exercício do Poder Legislativo, do Poder Judiciário, do Ministério Público e dos Poderes constitucionais das unidades da Federação, o exercício dos direitos políticos, individuais e sociais, a segurança interna do País, a probidade na administração, a lei orçamentária e o cumprimento das leis e das decisões judiciais.

A propósito da cláusula aberta do que venha a ser crime de responsabilidade, a própria Constituição estatui, no art. 85 , caput, que "são crimes de responsabilidade os atos do Presidente da República que atentem contra a Constituição Federal". Só depois de fixar essa regra básica é que se acrescentou: “e, especialmente, contra [...]”, seguindo-se os sete incisos exemplificadamente postos em relevo pelo constituinte, que incumbiu o legislador da tarefa de 
decompô-los e enumerá-los. Observa-se que a Constituição mesma prescreveu que todo atentado, toda ofensa a uma prescrição sua, independente de especificação legal, constitui crime de responsabilidade (BROSSARD, 1992, p. 53).

A locução crime de responsabilidade, que "entrou na Constituição sem exato conceito técnico ou científico" - a sentença é de José Frederico Marques (1961, p. 45) -, não necessariamente possui correlação com uma infração penal. Quando motiva o impeachment, sem dúvida - a despeito do nomen juris batizado pela Constituição e pela Lei que a complementa -, o ilícito a ele subjacente não é penal. O mesmo Marques (1961, p. 45) observa que "se o crime de responsabilidade não é sancionado com pena criminal, como delituoso não se pode qualificar o fato ilícito assim denominado, pois o que distingue o crime dos demais atos ilícitos é, justamente, a natureza da sanção abstratamente cominada".

A falha terminológica, que reiteradas vezes pode ser lida na vigente redação constitucional, refere-se de modo equívoco a crimes de responsabilidade ora com sentido de infração política, ora na acepção de crime funcional, concorrendo para a defectiva sistematização do instituto concernente à responsabilidade presidencial (BROSSARD, 1992). A deficiência, todavia, não é originalidade da Constituição de 1988. Depara-se com ela já na Constituição republicana de 1891 , tendo persistido nas seguintes. "A ausência de tratamento sistemático da matéria parece haver contribuído para que a força da inércia se fizesse sentir com a simples e inadvertida repetição de textos de uma a outra Constituição", observa Brossard (1992, p. 64).

É que antes da proclamação da República, precisamente durante o Primeiro e o Segundo Reinados, os crimes de responsabilidade, dissessem respeito a Ministros de Estado ou a outros funcionários públicos, eram sancionados com pena criminal. Desde então, a expressão crime de responsabilidade se insinuou na linguagem legislativa e não mais foi abolida. Empregada nas leis do antigo regime, com referência a autoridades políticas e a servidores públicos, teve ingresso e curso fácil nas leis republicanas, embora no novo regime tenha se estabelecido a separação entre os juízos político e penal. Portanto, com a República, a responsabilidade política deixou de ser criminal. Com razão, Brossard (1992, p. 69) pondera que, se os crimes de responsabilidade, enquanto relacionados a ilícitos políticos, fossem denominados de infrações políticas, melhor se atenderia à natureza das coisas e se evitaria a confusão decorrente da designação, pelo mesmo nome, de realidades diversas. 


\subsection{Da natureza jurídica do impeachment}

Passa-se à análise da consequência política que pode advir do cometimento de um crime de responsabilidade pelo Presidente da República: o impeachment. O vocábulo foi incorporado à língua inglesa, na qual o verbo to impeach ganhou o sentido genérico de acusar, culpar, contestar, impedir. Todavia, em termos jurídico-políticos, passou-se a designar por impeachment o sentido de imputação, destituição, desvestimento.

$\mathrm{Na}$ Inglaterra, o impeachment foi a ferramenta liberal criada para, indiretamente, responsabilizar-se a figura do rei, por meio de uma acusação formulada contra um de seus ministros, já que o monarca estava protegido por total irresponsabilidade, assentada na máxima segundo a qual o rei não pode fazer o mal (the king cannot do wrong). Conforme se percebe até aqui, o instituto do impeachment nasceu na Inglaterra, dali passando para os Estados Unidos da América, onde, enclausurado pela codificação, adquiriu feição republicana, oferecendo maior rigidez ao processo e maior garantia ao acusado, porque não basta que este contrarie a política do Congresso, mas é preciso que ofenda diretamente a Constituição. Por seu turno, o impeachment inglês, com o correr dos tempos e a consolidação do sistema parlamentarista, transformou-se, pelo common law, no voto parlamentar de censura ou desconfiança, que, de modo rápido, afasta do governo a autoridade que haja decaído da confiança da maioria, o que será estudado na próxima seção.

Em síntese, no terreno republicano, se, por um lado, o Presidente da República perdeu a intangibilidade que cercava o monarca, por outro, ele está garantido pelo due process of law, quando denunciado. Indiscutivelmente, no sistema presidencialista, em que o Chefe do Executivo, tanto quanto o Parlamento, é sufragado pelo voto popular para cumprir um mandato estável, o rigor litúrgico do impeachment encontrou sua conformação políticojurídica ideal.

Na verdade, o impeachment no Brasil não nasceu com a República Presidencialista. $\mathrm{Na}$ Constituição de 1824, encontrou ele sua primitiva configuração. Se naquele tempo o Imperador não estava sujeito a nenhuma responsabilidade, os Ministros de Estado, pelos quais Sua Majestade exercitava o Poder Executivo, todavia, eram responsáveis por traição; por peita, suborno ou concussão; por abuso do poder; pela falta de observância da lei; pelo que obrassem contra a liberdade, segurança, ou propriedade dos cidadãos; e por qualquer dissipação dos bens públicos (art. 133). Por sua vez, o art. 134 estabelecia que "uma Lei 
particular especificará a natureza destes delictos, e a maneira de proceder contra elles”. O art. 135, a seu turno, assegurava que "não salva aos Ministros da responsabilidade a ordem do Imperador vocal, ou por escripto" (VERDE SOBRINHO; MORAES, 2016a).

Por conseguinte, já é possível destacar aquilo que de essencial distingue o processo de responsabilidade no presidencialismo do equivalente no parlamentarismo: a existência de uma infração política, ou seja, um crime de responsabilidade, que consiste numa violação ao texto constitucional. Somente diante de uma conduta comissiva ou omissiva do Presidente que vulnere, de modo direto e relevante (juízo político), algum princípio ou regra expressos na Constituição, é que se pode deflagrar o processo de impeachment.

Por violação direta e relevante entende-se aquela que malfere normas-pilares da Constituição, cuja fissura compromete os princípios fundamentais da República Federativa do Brasil e os direitos e garantias fundamentais, violação esta diante da qual somente o impeachment se apresentaria como sanção capaz de reparar o dano causado pela ação ou omissão inconstitucional do Presidente. Esta não seria a hipótese, por exemplo, de um ato presidencial, externado por Decreto ou Medida Provisória, que normatizasse matéria adstrita à reserva legal. Nesse caso, o próprio sistema de freios e contrapesos, a tempo e sem traumas, é naturalmente capaz de resolver a violação no seu nascedouro, expelindo do ordenamento jurídico a inconstitucionalidade perpetrada pelo Presidente, seja pela rejeição da MP pelo Congresso Nacional, seja pela invalidação judicial do Decreto, consequências jurídico-políticas suficientes para solucionar o impasse. Já a violação de direitos humanos ou da soberania nacional, a corrupção ou a fraude, por exemplo, solapam valores nucleares da Constituição.

Diferentemente, o sistema parlamentarista não exige violação à Constituição para a destituição do Chefe de Governo, bastando, em tal regime, por exemplo, a simples inépcia do primeiro-ministro, o descumprimento, por parte deste, de um acordo político firmado, a perda do apoio da maioria parlamentar ou até mesmo a prática de um ato privado tido por indiscreto e violador dos bons costumes (SARTORI, 1996; MORAES, 1993; LINZ, 1991).

A sanção de impeachment contra o Presidente da República, sem o cometimento de um crime de responsabilidade, representa confisco de mandato, pois sem o fato gerador da responsabilização, não pode haver a consequência sancionatória. Assim, por exemplo, destituir um Presidente em razão de sua política econômica desastrosa, por ocasional 
impopularidade nas ruas ou porque perdeu o apoio da maioria parlamentar são motivações incompatíveis com o sistema presidencialista, e que não podem servir de fundamento para o impeachment ${ }^{4}$.

No que respeita à iniciativa do processo, predomina o princípio da livre denunciabilidade popular, na medida em que é permitido a qualquer cidadão denunciar o Presidente da República ou Ministro de Estado, por crime de responsabilidade, perante a Câmara dos Deputados, conforme preceito do art. 14 da Lei $\mathrm{n}^{\circ} 1.079 / 1950$. Se os fatos imputados carecerem de produção de provas mais contundentes, antes da deflagração do processo pode-se instaurar uma comissão parlamentar de inquérito (VERDE SOBRINHO; MORAES, 2016b).

Quanto ao papel do Presidente da Câmara, já decidiu o STF que a este compete o “exame liminar da idoneidade da denúncia popular, que não se reduz à verificação das formalidades extrínsecas e da legitimidade de denunciantes e denunciados", mas se pode estender à "rejeição imediata da acusação patentemente inepta ou despida de justa causa", sujeitando-se ao controle do plenário da casa, pela via recursal (MS 20941, Rel. p/ Acórdão Min. Sepúlveda Pertence, Tribunal Pleno, julgado em 09/02/1990, DJ 31-08-1992). Ainda de acordo com o STF, o recebimento operado pelo Presidente da Câmara configura "juízo sumário de admissibilidade da denúncia para fins de deliberação colegiada, e não há obrigatoriedade de defesa prévia a essa decisão" (trecho do voto do Min. Edson Fachin na ADPF 378).

Recebida a denúncia popular pelo Presidente da Câmara, esta será lida no expediente da sessão seguinte e despachada a uma comissão especial eleita, da qual participem, observada a respectiva proporção, representantes de todos os partidos. A comissão terá um presidente e um relator, cabendo a este último a elaboração de um parecer

\footnotetext{
4 Merece atenção Aníbal Pérez-Liñán (2016, on line), quando, analisando a conjuntura brasileira atual, observa: "Las condiciones que impulsan los juicios políticos de hoy son en parte las mismas que impulsaban los golpes militares del pasado: recesión económica, movilización social y élites inescrupulosas. Pero el resultado no es igual. Llamar golpistas a los amplios sectores que piden - equivocadamente, en mi opinión - la salida de Dilma por juicio político significa legitimar con un barniz mayoritario a los verdaderos golpistas brasileños, quienes reivindican todavía el golpe militar de 1964”. O mesmo Pérez-Liñán (2007) aborda, comparativamente, diversos países sul-americanos frente ao que denomina "crises presidenciais" e a emergência de recorrentes “juicios políticos". Talvez não seja temerário esperar que, no making constitutions - a expressão é de Negretto (2013) -, ou no remaking constitutions, definam com maior precisão o que, no presidencialismo, é o impeachment ou juicio político.
} 
sobre a denúncia, recomendando o seu prosseguimento ou o arquivamento, o que será discutido e votado pela comissão, depois de ouvida a acusação e a defesa, para na sequência ser submetido ao plenário da Câmara. O plenário, e somente pela vontade de dois terços de seus membros, é que pode autorizar ao Senado Federal a abertura do processo de impeachment. Mas atenção: autorizar não significa determinar. Em razão disso, o Senado, a quem compete, privativamente, processar e julgar o Presidente, não fica obrigado a deflagrar o processo.

Aportada a matéria no Senado, o quórum deste para exercer o juízo de instauração do processo é de maioria simples, presente a maioria absoluta de seus membros, baseado em parecer previamente elaborado por uma comissão especial de senadores, depois de ouvir a acusação e a defesa, à semelhança da comissão de deputados. Instaurado o processo por decisão plenária, o Presidente da República ficará suspenso de suas funções. A partir desse momento, o Presidente do Supremo Tribunal Federal assume a presidência do processo no Senado, e tem início a fase de instrução processual. O Presidente já afastado deve apresentar defesa e eventualmente requerer produção de provas, podendo a acusação fazer o mesmo. Se, decorrido o prazo de cento e oitenta dias, o julgamento não estiver concluído, cessará o afastamento do Presidente processado, sem prejuízo do regular prosseguimento do processo.

Concluída a instrução, defesa e acusação deverão apresentar alegações finais. Depois, a comissão especial terá de elaborar novo parecer, agora sobre o mérito da denúncia. Este opinativo, após discutido e votado pela comissão, segue para o plenário, onde a votação só precisa de maioria simples para a continuidade do processo. Aprovado em plenário, terá início nos próximos dias a fase de julgamento, na qual acusação e defesa, com as respectivas testemunhas, exercerão mais uma vez o contraditório, bem como os senadores farão uso da palavra para inquiri-las e para debater a matéria dos autos.

O juízo de condenação somente será atingido com o quórum de dois terços dos senadores, restando assim o Presidente sentenciado à perda do cargo e à inabilitação, por oito anos, para o exercício de função pública, não havendo dosimetria, tampouco alternatividade de penas (art. 52, par. ún., da CRFB) ${ }^{5}$. Cumpre anotar que todas as votações referidas devem ser abertas, precedidas sempre do exercício do contraditório e da ampla defesa.

5 "No sistema atual, da Lei 1.079, de 1950, não é possível a aplicação da pena de perda do cargo, apenas, nem a pena de inabilitação assume caráter de acessoriedade" (STF, MS 21.689, Rel. Min. Carlos Velloso, 
Acrescente-se que ao julgamento parlamentar do impeachment não se aplicam as hipóteses de impedimento e suspeição de julgadores. A diferença de disciplina se justifica pela "distinção entre magistrados, dos quais se deve exigir plena imparcialidade, e parlamentares, que podem exercer suas funções, inclusive de fiscalização e julgamento, com base em suas convicções político-partidárias", devendo buscar realizar a "vontade dos representados" (trecho extraído da ementa da ADPF 378). A própria etimologia da palavra partido, aliás, evidencia que seus filiados são partes interessadas no resultado final, o que torna sui generis esse julgamento, que, como visto, é jurídico e é político.

Em síntese, no processo por crimes de responsabilidade do Presidente da República, há dois momentos: o da pronúncia e o do julgamento. A Câmara dos Deputados é tribunal de pronúncia, e o Senado Federal, tribunal de julgamento (art. 80 da Lei $n^{\circ}$ 1.079/1950). A Câmara decide sobre a admissibilidade da denúncia popular; o Senado é encarregado do processo e do julgamento do Presidente.

Conforme visto linhas atrás, o processo de responsabilidade perante o Parlamento constitui um circuito político-jurídico de apreciação e valoração de condutas políticas (LOMBA, 2008). Sendo assim, não resta dúvida de que o impeachment é instituto de caráter político, mas adstrito a um rito jurídico por excelência. Devem os julgadores, por isso, reverenciar o princípio do devido processo legal (CRETELLA JÚNIOR, 1992).

Assim como no Direito norte-americano, o impeachment brasileiro não visa punir delinquentes, mas proteger o Estado. Não atinge a pessoa, nem seus bens, mas simplesmente desveste a autoridade de sua capacidade política (BROSSARD, 1992). Portanto, o impeachment não representa um processo criminal; é um processo de natureza política, que busca não a punição de crimes, mas simplesmente afastar do exercício do cargo o governante que mal gere a coisa pública, e, assim, a destituição também não é uma pena criminal.

\footnotetext{
julgamento em 16-12-1993, Plenário, DJ de 7-4-1995). Em que pese a clareza redacional do art. 52, parágrafo único, segundo o qual a condenação à perda do cargo se dará "com inabilitação, por oito anos, para o exercício de função pública", o Senado Federal, no julgamento da então Presidente Dilma Rousseff em 2016, decretou a perda do cargo, sem inabilitação por oito anos, contrariando assim o enunciado da norma e a interpretação do STF dada no MS 21.689 (impeachment do ex-Presidente Fernando Collor, em 1992). O Senado, no caso Dilma, em equivocada leitura da CRFB, entendeu que as sanções são autônomas, promovendo na mesma sessão duas votações em forma de quesitos: uma para a destituição, outra para a inabilitação. Somente no primeiro escrutínio atingiu-se a maioria favorável de dois terços dos Senadores, restando aplicada apenas parcialmente a sanção prevista na Constituição, desrespeitando-se a regra que estabelece a concomitância punitiva.
} 
No que diz respeito ao resultado obtido (destituição do governante), o impeachment se assemelha ao voto de desconfiança utilizado nos sistemas parlamentaristas. Quanto às dessemelhanças, vimos que o impeachment exige a confirmação da prática de um crime de responsabilidade. Outra diferença reside no rigor ritualístico de um e de outro, sendo o processo de impeachment bem mais rígido, oferecendo maiores garantias ao acusado. Esse rigor se justifica a partir da constatação de que é muito mais traumático para a democracia despojar da chefia de governo alguém que foi eleito pelo voto popular, do que aquele que foi escolhido indiretamente para o cargo, seja por indicação do Chefe de Estado (rei ou presidente), seja por eleição dos pares no Parlamento.

A propósito, no processo político, as infrações devem ser apreciadas e julgadas em relação à conduta geral da autoridade (BROSSARD, 1992). E tais sejam as circunstâncias, quem sabe não ocorrerá aquilo que Ruy Barbosa (1953, p. 109) admitiu: "muitas vezes, reconhecendo mesmo a existência de faltas, de erros e de violações das leis, o Congresso terá de recuar ante as consequências graves de fazer sentar o Chefe do Estado no banco dos réus".

\section{A RESPONSABILIDADE POLÍTICA NO PARLAMENTARISMO}

O parlamentarismo representa o ponto de chegada da evolução política das instituições inglesas, cujas origens mais remotas se situam nos primeiros séculos da monarquia britânica (BONAVIDES, 2015). Diferentemente do presidencialismo, organizado teórica e institucionalmente pelos constituintes americanos de 1787, o governo parlamentar foi paulatinamente construído pela experiência política inglesa (HUME, 2015; MCILWAIN, 2007; BAGEHOT, 2001; FRANCO, PILLA, 1999), na síntese - proposta por Burke (2015) do princípio seguro de conservação com o princípio de transmissão, sem jamais excluir o princípio de aperfeiçoamento.

Os reis ingleses, já antes da invasão normanda ocorrida no século XI, tinham como órgão auxiliar da administração do reino um Conselho Privado (Privy Council), formado de nobres e dignitários que gozavam da intimidade e da confiança dos monarcas. Tal Conselho, cujas atribuições variavam ao sabor da menor ou maior confiança atribuída pelo soberano, discutia e decidia sobre questões importantes, relativas à administração e à política. Sempre que o rei devia praticar algum ato importante, era costume recorrer aos conselheiros. A seu tempo, o número excessivo de membros levava o autocrata a preferir um número menor de 
pessoas e nelas depositar a sua confiança, fazendo com que do Conselho Privado se retirasse um comitê. Deste grupo se originou o gabinete do governo parlamentar, formado pelos ministros do rei.

Gradativamente, durante os cerca de trezentos anos que antecedem a Revolução Gloriosa (1688), o Conselho vai adquirindo força e prestígio, cumulando por conquistar independência, fiscalizando e discutindo com altivez os assuntos de governo, contendo excessos, sobretudo os de arrecadação de impostos. Circunstância fortuita ensejou a independência do gabinete, permitindo, enfim, que se transformasse em um Poder Executivo governando com o apoio do Parlamento: o fim da dinastia dos Stuart e assunção dos Hannover, os "reis alemães". Sem falar inglês, os dois primeiros monarcas da nova dinastia transferiram ao colegiado de ministros as discussões e decisões, incumbindo a um dos pares, geralmente o membro mais ilustre, de apresentar-lhes as resoluções aprovadas, surgindo daí, com o passar do tempo, a figura do primeiro-ministro (VERDE SOBRINHO; MORAES, 2017).

Bonavides, contudo, observa que "o Parlamento verdadeiramente só se forma com a aparição da Câmara dos Comuns, ramo resultante da associação da burguesia ascendente com a pequena e média nobreza rural". Com a cisão da nação feudal no curso do século XIX, ficando de um lado os grandes barões feudais agrupados, gravitando ao redor do rei, e de outra parte, a média aristocracia aliada com a burguesia, em defesa de suas liberdades, estava consumado o advento da Câmara dos Comuns, verdadeiro começo do Parlamento, com a implantação, já a esta altura incontestável, do sistema representativo (BONAVIDES, 2015, p. 343-344).

Foi assim, pois, da luta entre a burguesia ascendente e a aristocracia descendente que a Inglaterra acabaria por institucionalizar o Poder Legislativo e o Poder Executivo, lançando as sementes da monarquia constitucional, do sistema representativo e do parlamentarismo.

Mas ainda faltava resolver outro problema, o da responsabilidade dos governantes, já que não seria racional tirar o governo das mãos de um monarca politicamente irresponsável e colocá-lo nas mãos de um grupo de governantes igualmente sem contas a prestar à nação. Seria substituir um único déspota por um grupo deles. Por tal fundamento, o sistema representativo, então nascente, surgiu intimamente ligado às ideias de responsabilidade e controle políticos, constatando-se, hoje, que "as oposições são o agente natural do exercício 
da função de controlo político" (SEGURO, 2016, p. 109). Bonavides (2015, p. 344-345) aponta que a ascensão política do Parlamento resultou num novo princípio do Direito público inglês: em caso de pendência com o poder representativo, os ministros decaídos da confiança do Parlamento "ficariam sujeitos a um processo de responsabilidade, em que caberia a acusação à Câmara dos Comuns e o julgamento à Câmara dos Lordes”. A esse processo deuse o nome de impeachment.

Adquirido depois pelos ministros o hábito de se demitirem voluntariamente, se porventura lhes minguasse a confiança do Parlamento, por temor de que se consumasse a ameaça pendente do impeachment, estava então lançada a pedra angular do sistema (BONAVIDES, 2015, p. 346), restando, pela tradição do common law, transmutado o impeachment, de excessivo rigor ritualístico, no vote of no-confidence, que, de modo rápido, afasta do governo a autoridade que haja decaído da confiança da maioria.

Vê-se, com isso, que o voto de desconfiança ou censura representa uma evolução do impeachment. No entanto, o impeachment, no parlamentarismo, caiu em desuso, vindo a encontrar ambiência favorável no presidencialismo, no qual as destituições de governo, pela própria essência do sistema, exigem um processo solene, com fundamentação jurídica, de múltiplas fases e com amplo exercício do contraditório e da ampla defesa.

Despertando a atenção dos estudiosos e estadistas - com construções, esquematizações, idealizações e interpretações (SCHMITT, 1992) - o modelo parlamentarista se projetou das ilhas britânicas em direção ao continente. Na França, em 1814, promover-se-ia a primeira expressão no Direito Constitucional escrito e daí se expandiria para outros países europeus, possibilitando até a atualidade uma congérie de formatos e experiências ${ }^{6}$.

O traço marcante do parlamentarismo é, por conseguinte, o fracionamento do Poder Executivo entre vários atores: o Chefe de Estado (um rei, nas monarquias, ou um presidente, nas repúblicas), o Chefe de Governo (comumente chamado de Primeiro-Ministro, Premier, Chanceler ou Presidente do Conselho de Ministros) e os Ministros de Estado. A depender da tradição de cada povo, o papel do Chefe de Estado é maior, como no caso do Presidente da

\footnotetext{
6 Schmitt (1992, p. 312) verberava a fetichização institucional concernente ao parlamentarismo inglês, destacando: "Frente a la idealización y simplificación del parlamentarismo inglés y frente a los intentos de imitarlo, también en el continente europeo destacados sabios y escritores han acentuado los supuestos de ese sistema inglés". No entanto, "el Parlamento ingles se convirtió, en el siglo XIX, para gran parte de la burguesía liberal, en un cuadro místico, con lo cual no se preocupaba de la corrección y verdad histórica".
} 
França, ou menor, podendo, inclusive, exercer apenas funções honoríficas, a exemplo da Rainha da Inglaterra.

Estabelece-se entre todos estes atores uma teia de relações institucionais marcadas por controle e fiscalização. Ao lado desse Poder Executivo, faz-se presente um Legislativo, uni ou bicameral, que também o fiscaliza, e em cujo seio é que se estabelece a agenda política do Estado, por ser o órgão de maior legitimidade democrática, com partidos políticos fortes e parlamentares fiéis às suas legendas.

\subsection{Das ferramentas parlamentaristas de responsabilização política}

No que atine à responsabilidade política do ministério parlamentarista, ela é promovida por meio de críticas qualificadas (COUTINHO, 2013), dirigidas a um, a alguns ou a todos os ministros, externadas em votações parlamentares, geralmente no âmbito da Câmara de representantes do povo, enquadradas nas seguintes espécies: (i) interpelações, (ii) votos ou moções de desconfiança ou censura e (iii) votos ou moções de confiança.

Nesse passo, tem-se que a interpelação geralmente é utilizada como ferramenta primeira da responsabilidade política, funcionando como um sinal amarelo de alerta ao governo. Ela é proposta por um ou por determinado número de deputados e submetida à aprovação do plenário. Se aprovada, cabe ao governo defender-se perante o Parlamento interpelador, por intermédio do primeiro-ministro ou especificamente de algum ministro responsável pelo tema relacionado à interpelação. Sua função, portanto, é dirimir dúvidas e esclarecer a opinião pública.

Se exitosa a defesa, o assunto ficará encerrado com a aprovação de um voto ou moção de confiança em favor do governo. Se rejeitada pela maioria, poderá ser proposto um voto ou moção de desconfiança, que, uma vez aprovado, resultará na queda do gabinete, com sua consequente substituição, ou na queda e substituição individual do ministro que não foi capaz de debelar os questionamentos da oposição. Todavia, para que haja voto de confiança ou de desconfiança, não necessariamente tem que ter havido prévia interpelação. Pode ocorrer que o próprio ministério, ao ser empossado ou quando tenha de conduzir o governo sob uma orientação diversa em face de determinado problema de importância vital, resolva pedir ao Parlamento um voto de confiança. Neste caso, o primeiro-ministro poderá justificar-se em plenário, submetendo desde logo o pedido à votação. Negada a confiança, o ministério restará obrigado a se demitir. 
Destarte, o voto ou moção de desconfiança ou censura é, por excelência, o instrumento de responsabilização política do sistema de governo parlamentar, cuja noção se traduz na possibilidade de o Parlamento julgar os atos do Poder Executivo no que concerne à observância do interesse público, baseado em razões de conveniência e oportunidade. Consoante Elvis Coutinho (2013, p. 8109), trata-se de uma "proposta parlamentar, manejada pela oposição, que visa derrotar ou constranger o governo e que tem como fundamento a contradição da posição por este adotada em desfavor do interesse público".

Decididamente, o governo tem de contar com a confiança do Parlamento, a quem ele presta contas, e é a quebra desse vínculo de confiança que possibilita o uso da moção de censura. Cumpre chamar a atenção de que, no sistema parlamentarista, a responsabilização política do governo independe do cometimento de uma inconstitucionalidade ou de uma ilegalidade, como ocorre no presidencialismo. Para que haja a destituição do gabinete, basta, de ordinário, que pela proposta de um grupo de membros da Câmara de representação popular, aprovada pela maioria absoluta dos respectivos pares, conclua-se que o governo não é mais capaz de satisfazer o interesse público, sendo-lhe imputado um voto de desconfiança.

De modo claro, as motivações têm índole essencialmente política, sem que configurem, necessariamente, atos contrários ao ordenamento jurídico. $\mathrm{O}$ voto de desconfiança julga equívocos políticos; o impeachment decide sobre ilícitos políticos, no Brasil chamados de crimes de responsabilidade, os quais, apesar da terminologia, não são figuras do Direito Penal, mas do Constitucional. Esta, sem dúvida, é a principal diferença entre o voto de desconfiança parlamentarista e o impeachment presidencialista; o primeiro assenta na conveniência e oportunidade; o segundo baliza-se pelas raias da legalidade, embora sem desprezo a elementos políticos ${ }^{7}$.

Frise-se, ademais, que, tecnicamente, o Parlamento não demite o ministério; este é que deve resignar-se e pedir demissão em face da manifestação de desconfiança. Caso permaneça, estará fora da legitimidade e da legalidade. Demitindo-se, normalmente compete

\footnotetext{
7 A propósito, deve ser sempre lembrada a advertência: "Entre nós, [...] como no direito norte-americano e argentino, o impeachment tem feição política, não se origina senão de causas políticas, objetiva resultados políticos, é instaurado sob considerações de ordem política e é julgado segundo critérios políticos, julgamento que não exclui, antes supõe, é obvio, a adoção de critérios jurídicos. Isto ocorre mesmo quando o fato que o motive possua iniludível colorido penal e possa, a seu tempo, sujeitar a autoridade por ele responsável a sanções criminais, estas, porém, aplicáveis exclusivamente pelo Poder Judiciário” (BROSSARD, 1992, p 75).
} 
ao Chefe de Estado (rei ou presidente) indicar, dentre os membros da Câmara de representação popular (Assembleia Nacional, Federal ou da República, Câmara Baixa, Câmara dos Comuns, Câmara dos Deputados etc.) um político honrado, habilidoso e influente, cujas convicções ideológicas estejam em harmonia com o pensamento parlamentar dominante, para, formando o novel colégio governamental, conduzir um novo governo.

De regra, os ministros auxiliares são escolhidos pelo primeiro-ministro dentre os mais destacados do Parlamento, retirados do partido majoritário, onde há bipartidarismo, ou dos partidos que formam a coalizão do governo, onde há pluripartidarismo, podendo pertencer a qualquer das câmaras, onde haja bicameralismo. Esta orientação não emana da lei, mas da lógica, pois representa o caminho mais eficiente para a obtenção da confiança do Parlamento.

\subsection{Do voto de desconfiança contra o governo}

Os efeitos do voto de desconfiança objetivam a substituição do governo, convindo analisá-lo a partir dos tipos existentes, assim usualmente identificados pela Ciência Política: (i) o voto de desconfiança stricto sensu; e (ii) o voto de desconfiança construtivo (COUTINHO, 2013, p. 8109).

No que diz respeito ao voto ou moção de desconfiança ou censura stricto sensu, é o modelo clássico utilizado nos sistemas parlamentaristas, de iniciativa da oposição, cujo objetivo é tão somente forçar a demissão do ministério, ficando para um segundo momento as discussões e a votação quanto à nomeação de um novo gabinete. Os debates e a eleição travam-se na Câmara dos representantes do povo. Quanto ao número mínimo de assinaturas para que a moção seja submetida ao plenário, este naturalmente varia de acordo com cada ordenamento jurídico. A título de ilustração, menciona-se o exemplo português, onde se exige um quarto dos Deputados ou qualquer grupo parlamentar; o espanhol, o italiano e o francês, com um décimo dos Deputados. O quórum para aprovação do voto, em praticamente todos os modelos, é de maioria absoluta.

Já o voto de desconfiança construtivo, mais que objetivar simplesmente a dissolução do governo despojado da confiança do Parlamento, impõe a concomitante indicação de um novo governo (COUTINHO, 2013, p. 8111), evitando soluções de continuidade ou hiatos governamentais. Dessa forma, o voto só poderá ser pronunciado se a Câmara eleger, por maioria absoluta, um sucessor para a função de primeiro-ministro, o que restringe, 
sensivelmente, as possibilidades de efetivação de tal medida. Espanha e Alemanha adotam essa ferramenta (TAVARES, 1988).

Em praticamente todos os modelos de parlamentarismo existem mecanismos destinados ao uso racional e moderado das moções de censura, de modo a evitar abusos. Os principais institutos são o prazo de reflexão e a vedação à reapresentação de censura na mesma sessão legislativa em que já tenha sido confirmada a confiança no governo. O primeiro consiste num intervalo de dois a cinco dias, a depender de cada ordenamento, entre a apresentação do voto e a votação, para que nesse tempo haja um arrefecimento das paixões momentâneas, sempre prejudiciais às decisões políticas, e uma reflexão mais aprofundada, alinhando-se a vontade parlamentar com o interesse popular. O outro mecanismo consiste no seguinte: rejeitada a moção, não poderá ser apresentada outra na mesma sessão legislativa.

A seu tempo, há sistemas em que o gabinete é responsável apenas perante o Parlamento, e esta é a regra geral; outros existem em que os ministros, além do Parlamento, também prestam contas ao Chefe de Estado, a exemplo de Portugal; há ainda a forma na qual os ministros só prestam contas ao primeiro-ministro, e este, por sua vez, é responsável frente ao Parlamento, a exemplo da Alemanha. Existem ainda sistemas em que um ministro pode ser individualmente responsabilizado diante do Parlamento, a exemplo da Itália; outros existem cuja responsabilização é coletiva do gabinete, sendo este o padrão parlamentarista (TAVARES, 1988).

Quanto ao papel do Senado, Câmara Alta, Câmara dos Lordes ou Conselho Federal nos sistemas parlamentaristas bicamerais, cumpre observar que tal colegiado geralmente não compartilha com a Câmara de representantes do povo o mesmo grau de protagonismo e prestígio, como ocorre no presidencialismo. Todavia, embora em alguns casos seus poderes venham sofrendo diminuição constante, ainda mantém grande autoridade moral. Em alguns modelos, são órgãos de estudos, de investigações públicas, de revisão técnica e formal das leis aprovadas na Câmara, a exemplo do Canadá. Em outros, funcionam como Câmara revisora das propostas legislativas e como importante fórum de debates, como na Inglaterra. Há, porém, Estados onde o Senado goza de mais prerrogativas, aproximando-se da influência exercida pela Câmara. São exemplos a Alemanha, a Itália e a Espanha. Os senadores, a depender da respectiva Constituição, podem ser eleitos, direta ou indiretamente, para exercerem mandato ou nomeados de forma vitalícia (CAMBRAIA, 2009; TAVARES 1988). 
Por fim, deve-se ponderar que, à responsabilidade política do ministério perante a representação nacional, corresponde a prerrogativa atribuída ao Chefe de Estado para dissolver a Câmara em consulta à nação. De fato, o voto de desconfiança, principalmente quando secundado em tempo relativamente exíguo, revela uma situação de conflito entre os dois poderes políticos, cabendo então ao Chefe de Estado, atento às manifestações da opinião pública, resolvê-lo, como poder moderador, pelas alternativas de que dispõe: nomear novo gabinete ou dissolver o Parlamento representativo do povo. Eis o grande diferencial desse sistema: o equilíbrio alcançado pela inter-relação dos Poderes Legislativo e Executivo.

Resta claro, portanto, que o fundamento de legitimidade do voto de desconfiança é a satisfação do interesse público. É legítimo derrubar o governo que passou a amargar a antipatia do povo, mesmo que essa rejeição não possua causas jurídicas positivadas. Deve, por isso, o Parlamento ecoar fielmente a voz dos representados e espelhar com simetria plena os anseios da nação. Em contrapartida, o Parlamento que, divorciado desse fundamento, mire derrubar o Governo, atuará à margem da legitimidade, restando o Chefe de Estado autorizado a dissolvê-lo.

\section{CONSIDERAÇÕES FINAIS}

A responsabilidade política, se pudéssemos transformá-la numa fórmula de fácil compreensão, diríamos que ela é o resultado da soma da fiscalização com a potencial revogação da representação. Esta fórmula, por certo, aplica-se aos dois sistemas de governo aqui estudados, o presidencialismo e o parlamentarismo, porquanto se trata de uma ferramenta inerente ao Estado de Direito e à Democracia Representativa.

Não obstante a ambivalência sistêmica desta fórmula, há que se ter em mente as diferenças existentes na essência dos dois modelos de responsabilidade, em que pese haver entre eles um marcante traço de identidade, pois, se objetivamente considerados os resultados obtidos num e noutro, estes convergem quanto à sanção aplicável: uma sanção política, consistente na subtração da capacidade político-executiva da autoridade governante.

Por outro lado, aquilo que de essencial contrasta os dois processos de responsabilidade é, do lado do presidencialismo, a necessária existência de uma infração política, ou seja, um crime de responsabilidade, que consiste numa violação direta, nuclear, ao texto constitucional, assim entendida aquela que malfere normas-pilares da Constituição, cuja fissura compromete os princípios fundamentais da República Federativa do Brasil e os 
direitos e garantias fundamentais, violação esta diante da qual somente o impeachment se apresentaria como sanção capaz de reparar o dano causado pela ação ou omissão inconstitucional do Presidente. As demais violações, cujo sistema de freios e contrapesos, a tempo e sem traumas, seja naturalmente capaz de resolver, não estariam inseridas neste conceito. É preciso, pois, distinguir, em juízo político, os acidentes e os atentados, devendo recair sobre estes últimos a condenação política.

Nessa trilha, a sanção de impeachment contra o Presidente da República, sem a materialização de um crime de responsabilidade, representa confisco de mandato, atentado desvelado à democracia, na medida em que a ausência do fato gerador da responsabilização obsta toda e qualquer consequência sancionatória tendente à destituição do cargo. Não basta, portanto, que se observe o aspecto meramente formal do processo. Deve haver, no conteúdo, a perfeita subsunção do fato valorado a um tipo constitucional.

Contrariamente, o sistema parlamentarista não exige violação à Constituição para a destituição do Chefe de Governo, bastando, de ordinário, que pela proposta de um grupo de membros da Câmara de representação popular, aprovada pela maioria absoluta dos respectivos pares, conclua-se que o governo não é mais capaz de satisfazer o interesse público, sendo-lhe imputado um voto de desconfiança. $\mathrm{O}$ fundamento de legitimidade do voto de desconfiança é, portanto, a satisfação do interesse público, independentemente de causas jurídicas positivadas, devendo o Parlamento, a todo custo, espelhar com perfeita simetria os anseios da nação, sob pena de, divorciando-se desse fundamento, restar dissolvido pelo Chefe de Estado.

Ademais, diferem os sistemas no atinente ao rigor ritualístico de um e de outro processo de responsabilização, sendo o do impeachment bem mais rígido, solene, demorado - porquanto de rito bicameral - e servil a regras jurídico-políticas exaustivamente previstas na Constituição e minudenciadas por lei especial, oferecendo maiores garantias ao acusado.

Assim posta a questão, tem-se que o voto de desconfiança julga equívocos políticos; o impeachment decide sobre ilícitos políticos. O primeiro assenta na conveniência e oportunidade; o segundo baliza-se pelas raias da legalidade, embora sem desprezo a elementos políticos. A sanção presidencialista é voltada à figura individual do Presidente; a sanção parlamentarista, como regra, visa derrubar coletivamente o governo. 
À luz de tais constatações, não resta dúvida de que o dever constitucional de prestar contas decorre moralmente da transferência de poder, e que a responsabilidade política é o instituto essencial na concretização das democracias modernas. Todavia, o respeito às balizas constitucionais de cada modelo de responsabilização política é o elixir da legitimidade democrática. Vistas as semelhanças e as diferenças entre os processos e as sanções políticas de um e de outro sistema, conclui-se, finalmente, que é o interesse público que deve forçar a derrubada de governos, com serenidade e sem paixões, e somente em situações de gravidade tal que os métodos consensuais da política não tenham sido capazes de solucionar.

\section{REFERÊNCIAS}

BAGEHOT, Walter. The English constitution. Oxford: Oxford University Press, 2001.

BARBOSA, Ruy. Obras completas. Rio de Janeiro: Ministério da Educação e Cultura, 1953. v. XXV.t. VI.

BONAVIDES, Paulo. Ciência Política. 22. ed. São Paulo: Malheiros, 2015.

BROSSARD, Paulo. O impeachment. 2. ed. São Paulo: Saraiva, 1992.

BURKE, Edmund. Reflections on the revolution in France and other writings. London: Everyman's Library, 2015.

CAMBRAIA, Marcio Florêncio Nunes. O sistema político inglês. Tradição e bom senso. Revista Liberdade e Cidadania, Belo Horizonte, n. 6, out./dez. 2009. Disponível em: <http://www.flc.org.br/revista/arquivos/525363800784877.pdf>. Acesso em: 2 jun. 2016.

COUTINHO, Elvis Gibson Leite. Princípio da responsabilidade política. Revista do Instituto do Direito Brasileiro, Lisboa, n. 8, p. 8075-8117, 2013. Disponível em:

<http://www.cidp.pt/publicacoes/revistas/ridb/2013/08/2013_08_08075_08117.pdf>. Acesso em: 2 jun. 2016.

CRETELLA JÚNIOR, José. Do impeachment no Direito brasileiro. São Paulo: Revista dos Tribunais, 1992.

DAHL, Robert A. How democratic is the American constitution? New Haven and London: Yale Nota Bene, 2003.

FIGUEIREDO, Argelina Cheibub; LIMONGI, Fernando. Executivo e Legislativo na nova ordem constitucional. Rio de Janeiro: FGV, 1999.

FRANCO, Afonso Arinos de Melo; PILLA, Raul. Presidencialismo ou parlamentarismo? Brasília: Senado Federal, 1999.

HAMILTON, Alexander; MADISON, James; JAY, John. The federalist papers. New York: Signet Classics, 2003.

HUME, David. História da Inglaterra: da invasão de Júlio César à Revolução de 1688. Trad. Paulo Pimenta. São Paulo: Unesp, 2015. 
KETCHAM, Ralph (Ed.). The anti-federalist papers and the Constitutional Convention debates. New York: Signet Classics, 2003.

LINZ, Juan. Presidencialismo ou parlamentarismo: faz alguma diferença? In: LAMOUNIER, Bolívar (Org.). A opção parlamentarista. São Paulo: Idesp/Ed. Sumaré, 1991. p. 61-120.

LOMBA, Pedro. Teoria da responsabilidade política. Coimbra: Coimbra Editora, 2008.

MARQUES, José Frederico. Observações e apontamentos sobre a competência originária do Supremo Tribunal Federal. São Paulo: Saraiva, 1961.

MCILWAIN, Charles Howard. Constitutionalism: ancient and modern. Indianopolis: Liberty Fund, 2007.

MORAES, Alexandre de. Presidencialismo. 2. ed. São Paulo: Atlas, 2013.

MORAES, Filomeno. A discussão sobre o parlamentarismo e seus parâmetros. Nomos, Fortaleza, v. 11/12, n. 1/2, p. 195-204, 1993.

MORAES, Filomeno. A separação de poderes no Brasil pós-88: princípio constitucional e práxis política. In: SOUZA NETO, André Pereira de; BERCOVICI, Gilberto; MORAES, Filomeno; LIMA, Martonio Mont'Alverne Barreto. Teoria da constituição: estudos sobre o lugar da Política no Direito Constitucional. Rio de Janeiro: Lumen Juris, 2003. p. 151-197.

NEGRETTO, Gabriel L. Making constitutions: presidents, parties, and institutional choice in Latin America. New York: Cambridge University Press, 2013.

PÉREZ-LIÑAN, Aníbal. Presidential impeachment and the new political instability in Latin America. New York: Cambridge University Press, 2007.

PÉREZ-LIÑAN, Aníbal. Brasil: es preciso repensar el juicio político. Clarín, Buenos Aires, 25 abr. 2016. Disponível em: <http://www.clarin.com/opinion/Brasil-preciso-repensar-juiciopolitico_0_1564643616.html>. Acesso em: 30 jun. 2016.

ROSSITER, Clinton. American presidency. New York: New American Library, 1940.

SARTORI, Giovanni. Engenharia constitucional: como mudam as constituições. Trad. Sérgio Bath. Brasilia: UnB, 1996.

SCHMITT, Carl. Teoría de la constitución. Trad. Francisco Ayala. Madrid: Alianza Editorial, 1992.

SEGURO, António José. A reforma do parlamento português: o controlo político do governo. Lisboa: Quetzal Editores, 2016.

TAVARES, Ana Lucia de Lyra. Sistemas parlamentares contemporâneos. Revista de Ciência Política, Rio de Janeiro, v. 31, p. 15-87, 1988. Disponível em:

<http://bibliotecadigital.fgv.br/ojs/index.php/rcp/article/view/60104/58424>. Acesso em: 25 fev. 2016.

VERDE SOBRINHO, Luis Lima; MORAES, Filomeno. Parlamentarismo à brasileira no Segundo Reinado (1840-1889). In: LIMA, Martonio Mont'alverne Barreto; ZONARI, Mariana Luz; SOUZA, Alberto Dias de (Org.). Temas de Pensamento Constitucional Brasileiro. Rio de Janeiro: Lumen Juris, 2017, v. V. p. 127-146.

VERDE SOBRINHO, Luis Lima; MORAES, Filomeno. Poder moderador à brasileira na Constituição de 1824. In: MORAES, Filomeno (Coord.); KARAM, Andrea Maria Sobreira;

Revista de Teorias da Democracia e Direitos Políticos | e-ISSN: 2525-9660 | Brasília | v. 3 | n. 1 | p. 1 - 22 | Jan/Jun. 2017. 
SAMPAIO, Carolina Vasques; VIANA, Rafaela Gomes (Org.). Teoria do Poder. V. III. Belo Horizonte: Arraes, 2016a. p. 178-194.

VERDE SOBRINHO, Luis Lima; MORAES, Filomeno. Responsabilidade política no presidencialismo brasileiro: o impeachment no diálogo entre o julgamento político e a jurisdição constitucional. In: MORAES FILHO, José Filomeno de. BUSQUETS, Jose Miguel (Org.). Teoria e Filosofia do Estado: V Encontro Internacional do CONPEDI. Florianópolis: CONPEDI, 2016b, p. 61-81. Disponível em:

<http://www.conpedi.org.br/publicacoes/9105o6b2/hs2y306m/j1NipS31vwy2z8yI.pdf>. Acesso em: 7 mai. 2017. 